\title{
The literature of Romanian pneumophthisiology in the 19th century
}

\author{
Literatura pneumoftiziologiei românești în secolul al XIX-lea
}

\author{
Daniela Mihăilescu' ${ }^{1}$, Nicolae Marcu², Maria-Gabriela Suliman ${ }^{3}$ \\ ${ }^{1}$ Pneumologie Pediatrică, Institutul de Pneumoftiziologie „Marius Nasta“, București, România \\ ¿UMF “Carol Davila”, București, România \\ ${ }^{3}$ SRIF, București, România
}

\begin{abstract}
In this presentation there will be exhibited doctoral papers in medicine and surgery of the "current or old" internal physicians of the Civil Hospitals in Bucharest, of a battalion doctor, of a student of the medical-military boarding house, of an intern of the Colentinain the 19th century, with respect and gratitude to the teachers of the weather. With approaches to important subjects in the specialty, then, but now too. Well-trained and informed physicians both from literature and from the specialist, native experience and important achievements of the time.

The paper aims to present the significant contribution to the knowledge and medical experience of time, all of which are an important basis and contribution to what we are today in this specialty.
\end{abstract}

Keywords: pneumophthisiology, doctoral papers, 19th century

\section{REZUMAT}

În acest articol, sunt prezentate lucrări de doctorat în medicină și chirurgie ale medicilor "actuali sau vechi" interni ai Spitalelor Civile din București, a unui medic de batalion, a unui elev al internatului medico-militar, a unui intern al Spitalului Colentina în secolul XIX, cu abordări asupra subiectelor importante din specialitate de atunci, dar și de acum. Acești medici erau bine instruiți și informați atât din literatură, cât și din experiența de specialitate autohtonă și din realizările importante ale vremii.

Lucrarea îşi propune să prezinte aportul semnificativ al cunoștințelor și experienței medicale ale timpului, toate acestea reprezentând o bază și o contribuție importantă a ceea ce suntem astăzi, în această specialitate.

Cuvinte cheie: pneumoftiziologie, lucrări de doctorat, secolul XIX

\section{INTRODUCERE. CONTEXTUL ISTORIC}

Lupta cu tuberculoza, „boala secolului romantic“, era „socotită o suferință boemă, însoțitoare a iubirii într-o epocă în care a afla că ai tuberculoză echivala cu o condamnare timpurie la moarte".

În anul 1888, numărul de decese în București ajungea la cifra de 1000 , ceea ce ridica o grea problemă de soluționat pentru membrii Consiliului de Igienă și Salubritate Publică al orașului. A doua jumătate a sec. al XIX-lea a impus crearea și dezvoltarea unor pârghii instituționale care să facă față cerințelor de natură socială ale cetățenilor, de constituire a unui aparat medico-sanitar în stare să răspundă agresiunii maladiilor și epidemiilor care, de cele mai multe ori, din cauza condițiilor precare de igienă și a tratamentelor necorespunzătoare aplicate de către persoane fără studii de specialitate, sporeau rata de mortalitate.

Un moment important a fost reprezentat de acțiunea curajoasă și energică a medicului francez, naturalizat în Principate, Carol Davila, care, după Unire, în colaborare cu medicii autohtoni Nicolae Kretzulescu și Iacob Felix, unifică serviciile sanitare civile și militare din noul stat în scopul coordonării centralizate și eficiente. Este vorba de fondarea, 
în 1862, a Direcției Sanitare, cu sediul central la București, organizată prin fuziunea Comitetelor Sanitare din Moldova și Țara Românească.

În acest context, N. Georgescu, medic șef al Capitalei între anii 1892 şi 1905, va propune Epitropiei Spitalului Brâncovenesc să doneze barăcile din Dealul Filaret pentru realizarea, măcar temporară, a unui spital destinat exclusiv tuberculoșilor.

În 1898, a fost înființat, doar pentru o scurtă perioadă, primul post de medic comunal specializat în treburile ftiziei (profilaxie, identificare, ameliorare), ocupat de doctorul D. Ţinc, interesat îndeosebi de explorarea mediilor sărace, în care bacilul Koch găsea un teren propice dezvoltării.

La începutul secolului al XX-lea, în scopul combaterii problemelor de tuberculoză, a luat fiinţă primul cadru instituţionalizat, Spitalul Filaret din Bucureşti, care va activa întocmai ca o unitate de referinţă în domeniul profilaxiei şi contracarării acestei maladii.

\section{SCOP}

Lucrarea îşi propune să prezinte lucrări de doctorat în medicină și chirurgie ale medicilor „actuali sau vechi“" interni ai Spitalelor Civile din București, a unui medic de batalion, a unui elev al internatului medico-militar, a unui intern al Spitalului „Colentina“ în secolul XIX, cu abordări asupra subiectelor importante din specialitate de atunci, dar și de acum.
LUCRĂRI PREZENTATE (aflate în biblioteca UMF „Carol Davila“ București)

\section{Corsin loan, 1885 - „Câte-va cuvinte asupra tuberculosei ganglionilor limfatici la copii“}

Contribuţie ştiinţifică: Adenitele tuberculoase şi adenitele scrofuloase erau înglobate sub aceeaşi denumire de adenite tuberculoase; acestea, în absența unei complicații viscerale a tuberculozei, reprezintă o maladie ușoară; singurul tratament fiind extirparea [2].

\section{Staiculescu G., 1886 - „Meningita tuberculosa la copii"}

Contribuţie ştiinţifică: 1 . Meningita tuberculoasă la copii putea să aibă prodrom și debut cu totul altul de cel descris de autorii clasici; din cauza simptomelor care existau și în alte afecțiuni, diagnosticul devenea foarte dificil, dacă nu chiar imposibil. 2. Mersul meningitei tuberculoase se asemăna cu al unei meningite pur inflamatorii, cu mers lent. Erau utile antecedentele, uneori însă numai necropsia. 3. Prognosticul meningitei tuberculoase era aproape întotdeauna fatal, dar erau și cazuri de vindecare. 4. Vindecarea se făcea cu sau fără infirmități, fără a se putea preciza dacă era definitivă. Erau cazuri în care indivizi vindecați de meningita tuberculoasă au murit după 10-15 ani, tot de meningită tuberculoasă sau de tuberculoză pulmonară. 5. Singurele medicamente recomandate la acel moment erau Iodorul și Bromurul de

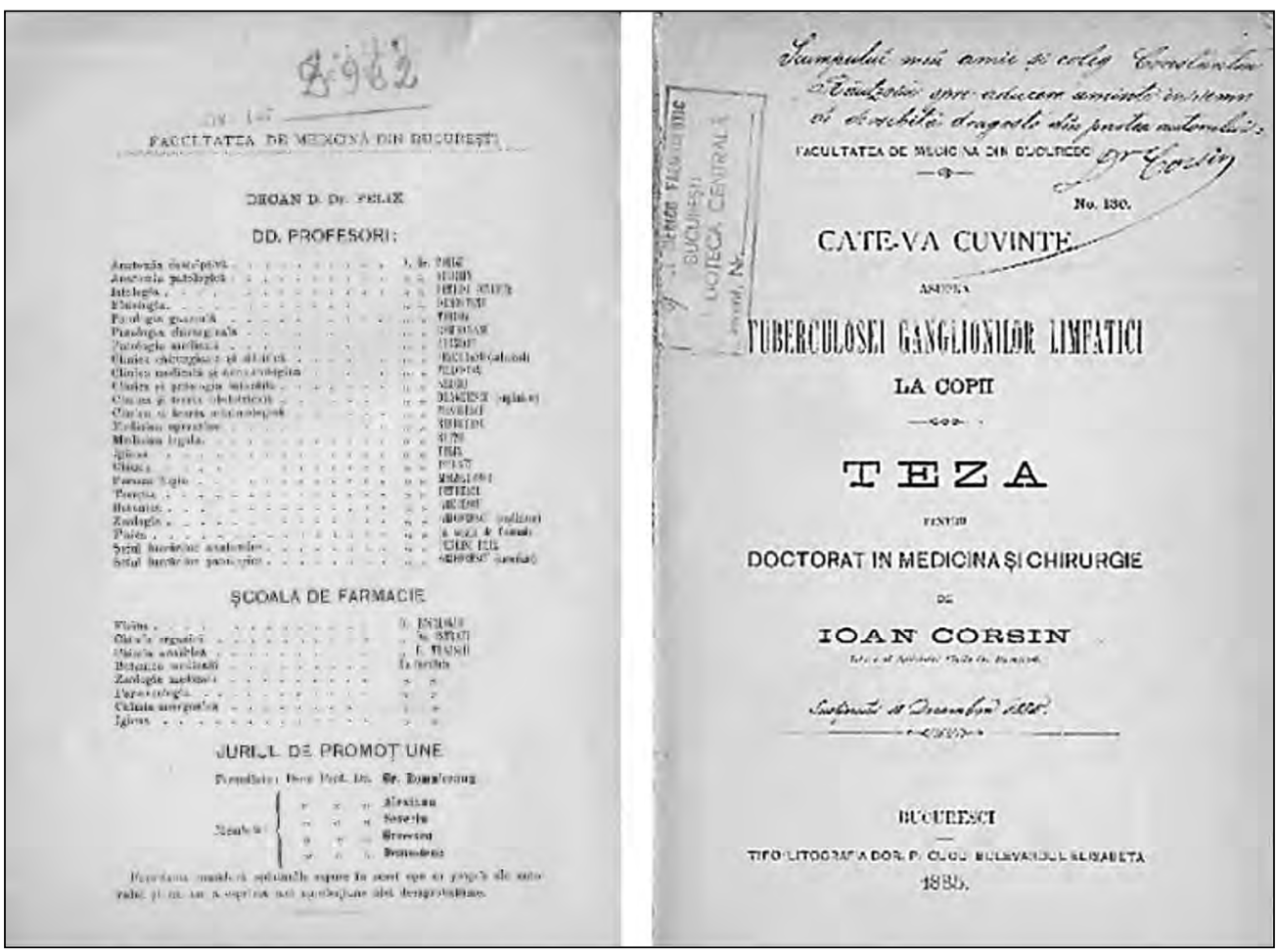




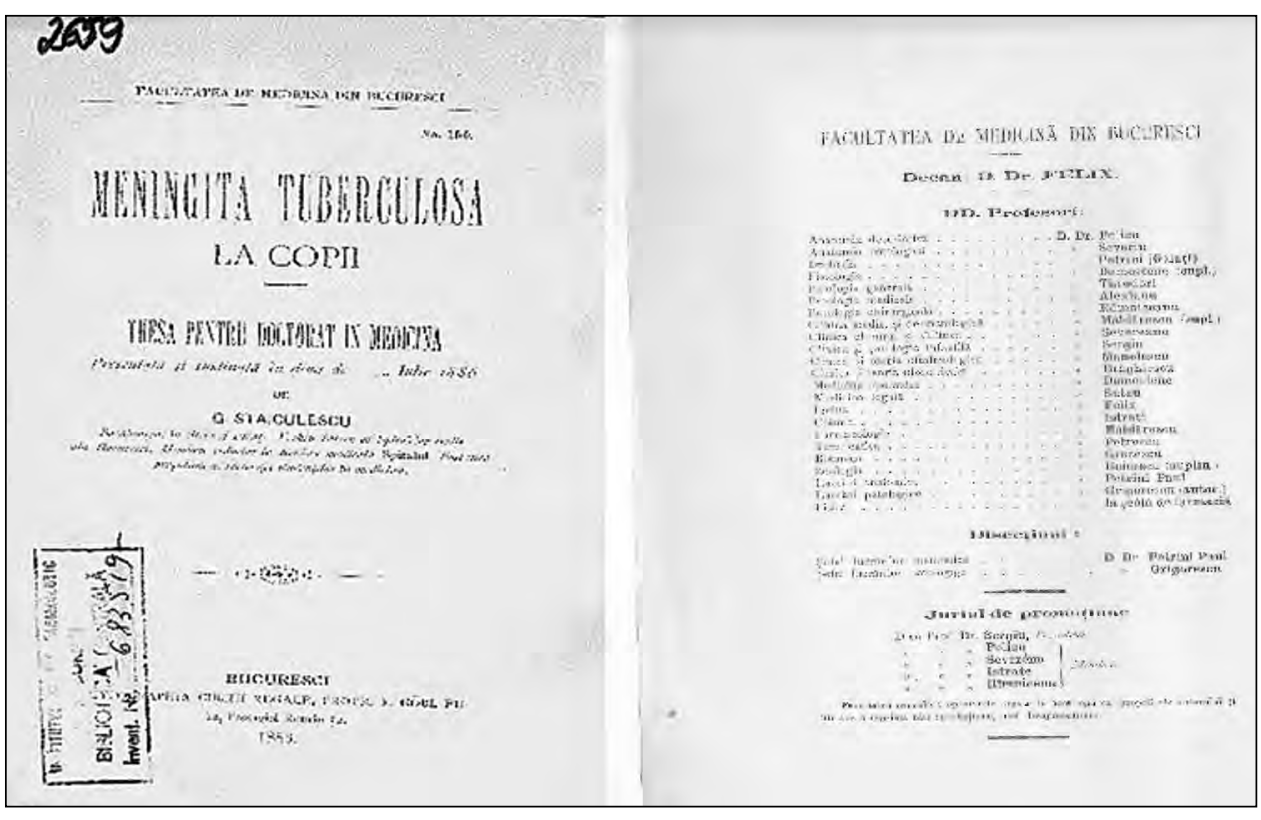

FIGURA 2. Lucrarea

Dr. Staiculescu G., 1886
Potasium, în doză mare, dar și vesicatorile și purgativele [3].

\section{Andrescu Vasile, 1887 - „Cercetări microbiologice asupra naturei absceselor peritoracice, dise tuberculose“}

Contribuţie ştiinţifică: 1. Cazurile folosite în cercetări au fost abcese reci peritoracice bine caracterizate prin simptomele lor clinice. 2. Examenul microscopic al celor opt cazuri cercetate a demonstrat numai într-un singur caz prezența celulelor gigantice și a bacilului tuberculozei, iar în celelalte șapte a arătat absența acestor elemente. 3. În șapte cazuri, microscopia a arătat următoarele microorganisme: Staphylococcus pyogenes aureus, Staphylococcus pyogenes citreus; Staphylococcus pyogenes albus; varietăți descrise de Rosenbacli. Bacillus pyocyaneus, descris de Gessart. Un alt microorganism nedescris până atunci aparținea genului Mycobacterium, care, după caracteristicele microscopice, după colorația ce o aveau coloniile sale în culturi pure și după produsul patologic din care fusese izolat, a fost denumit Micrococcus pyogenes aureus. 4. Prin inoculările pe animale, s-a constatat absența elementelor caracteristice tuberculozei. 5. Lipsa elementelor caracteristice tuberculozei în 7 dintre cele 8 cazuri a condus la concluzia că o bună parte dintre abcesele reci peritoracice nu erau tuberculoză. 6. În diagnosticarea abceselor reci, a declara o afecțiune tuberculoasă era o acţiune hazardată dacă nu era concomitentă unui examen microscopic afirmativ [4].

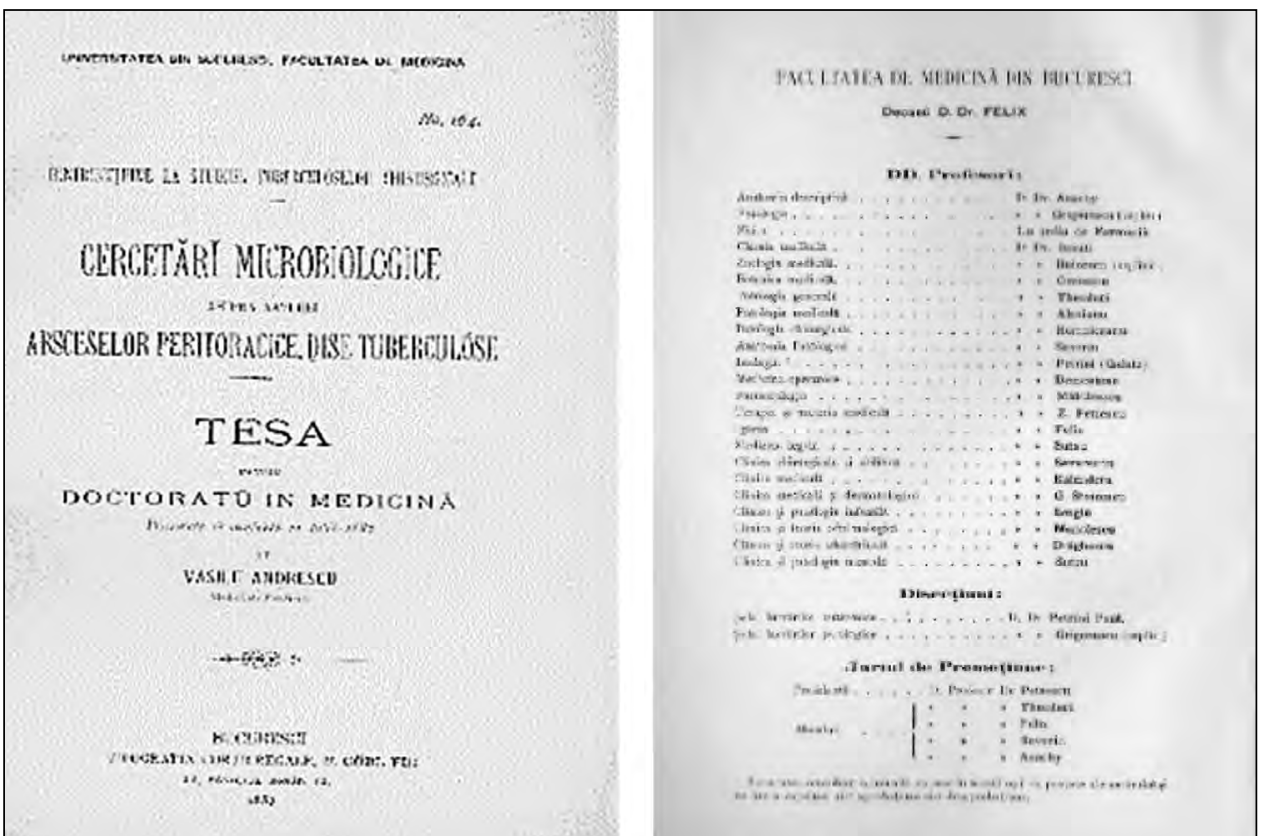

FIGURA 3. Lucrarea

Dr. Andrescu Vasile, 1887 


\section{Basilescu E.I., 1887 - „Despre tuberculosa vesicală“"}

Contribuţie ştiinţifică: Tuberculoza vezicală este primitivă sau secundară. 1. Cea secundară afecta bolnavii deja atinși de leziuni tuberculoase în alte organe și mai ales în plămâni. Cea primitivă era o localizare a tuberculozei care necesita o cauză favorabilă pentru a se putea dezvolta în acest organ. În multe cazuri, era o inflamație care făcea din vezică „locus minoris resistentise“. Tuberculoza vezicală era mai frecventă la om la vârste cuprinse între 15 şi 40 ani. 2. Leziunile în tuberculoza vezicală aveau sediu inițial în mucoasa conului și a trigonului într-o stare mai înaintată de dezvoltare decât în restul organului și mai numeroase. Pe lângă leziunile specifice (granulațiuni grise, granulațiuni galbene și ulcerații), se mai găseau și leziuni obișnuite ale inflamației vezicale. 3 . La început, tuberculoza se manifesta prin fenomene congestive și apoi inflamatorii. Micţiunile erau frecvente, imperioase, dificile, dureroase. Hematuriile erau în general puțin abundente, se produceau la începutul afecțiunii și erau sub influența congestiei; ele nu se modificau prin repaus. Hematuriile constau din firicele sanghinolente în depozitul purulent de la fundul vasului. Durerea era un simptom foarte important care se producea în timpul micțiunii, fiind provocată prin mișcări, presiune pe hipogastru, tușeul rectal sau vaginal, cateterism: nu se modifică prin repaus. Durerea era însoțită adesea de spasmul regiunii membranoase și de contractura colului, cauza fiind iritația produsă prin leziunile tuberculoase din regiunea cervicală. Acest spasm se datora uneori retenției urinare. Incontinența era consecința retenției. Se producea prin regurgitare, frecvent era vorba de o falsă incontinență. Cantitatea urinei era, în general, normală dar putea să existe uneori o poliurie, alternativ cu urina limpede și urina tulbure. Forma primitivă putea fi lungă și frecvent cu perioade de acalmie de mai mulți ani. Forma secundară evolua mai repede cu suferințe mai mari ale bolnavului și grăbea spre o formă letală. Era un prognostic grav, mai repede sau mai târziu putând să invadeze alte organe precum rinichi, plămâni etc. Moartea survenea prin caşexie, tuberculoză pulmonară, generalizată sau prin uremie. 4. Diagnosticul necesită luarea în considerare a tuturor simptomelor, modul lor de apariţie și cum se comportau, nu există un semn adevărat patognomonic de constatare a bacililor, dar prezența lor nu era mereu posibil de verificat. Antecedentele bolnavului, examenul toracelui și organelor genitale aveau mare valoare în punerea diagnosticului. Orice cistită spontană care se prelungea și rezista unui tratament era, în cele mai multe cazuri, o cistită tuberculoasă. 5. Tratamentul era medical; erau utilizate resurse variate: Medicație tonică și reconstituantă; Medicație calmantă. Tratamentul chirurgical era folosit în cazurile în care simptomele persistau terapiilor medicale, având ca scop suprimarea leziunilor vezicale; tratarea directă a leziunilor [5].

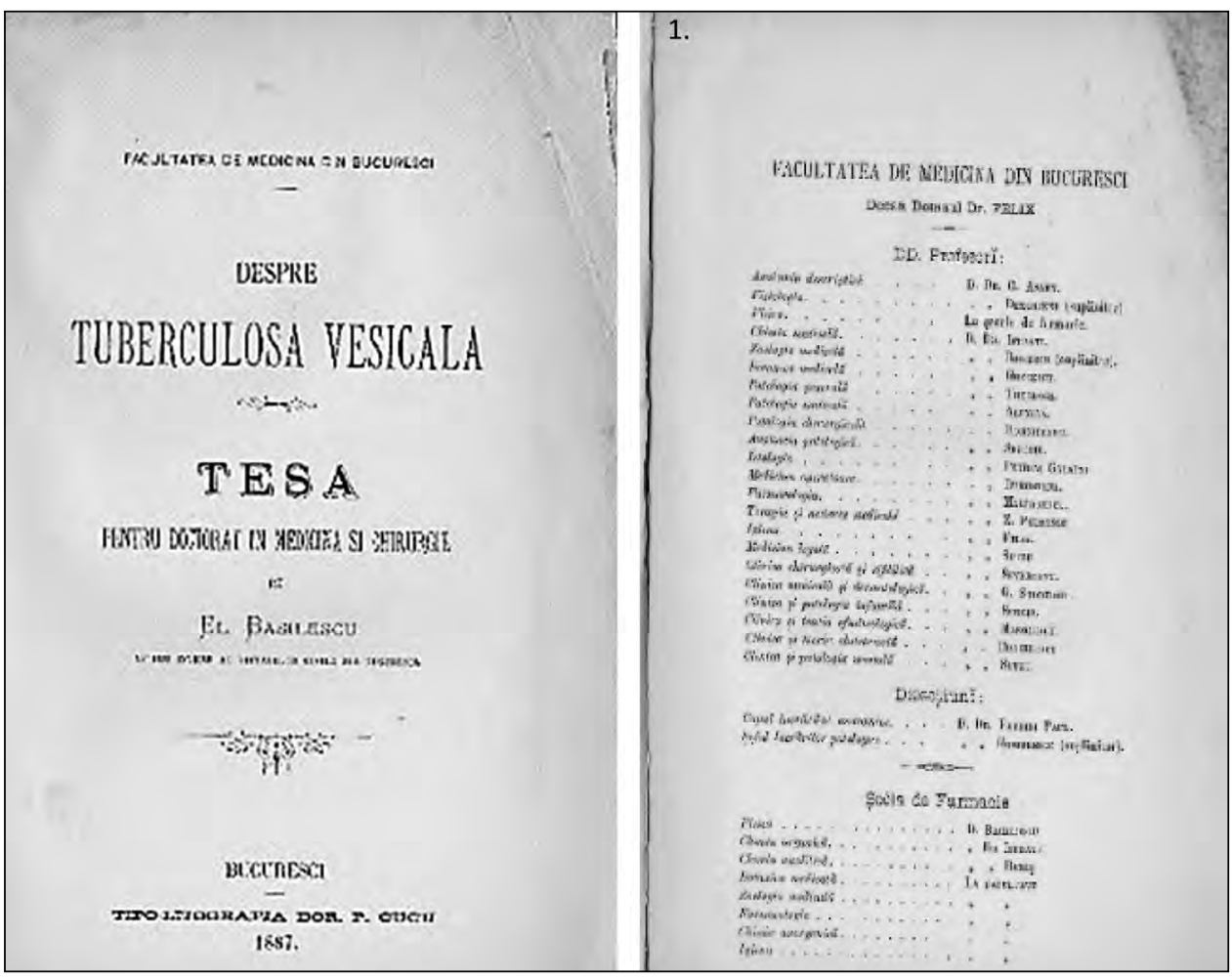

FIGURA 4. Lucrarea

Dr. Basilescu E.I., 1887 


\section{loanid Constantin, 1891 - „Câte-va cuvinte asupra pleuresielor serose în raport cu tuberculosa“"}

Contribuţie ştiinţifică: 1. Pleurezia de natură tuberculoasă era regula generală. Pleurezia a frigore idiopatică era excepție. 2. Natura exsudatului nu indică în mod absolut natura pleureziei; în majoritatea cazurilor, lichidul seros se observă în pleureziile tuberculoase; purulența lichidului nu era un semn de tuberculoză. 3. Lichidul seros era mult mai frecvent în pleureziile tuberculoase faţă de cel purulent. 4. Pleurezia sero-fibrinoasă era întâlnită la începutul sau în cursul tuberculozei pulmonare. 5. Ea putea fi și primitivă, putea să rămână izolată sau să constitue singura manifestare a tuberculozei. 6. La începutul tuberculozei pulmonare sau înaintea apariției semnelor fizice, putea fi abundentă, având toate aparențele pleureziilor a frigore; era puțin abundentă, manifestă, evidentă în perioadele mai înaintate. 7. Prognosticul imediat al pleureziei sero-fibrinoase zise a frigore era în genere benign, cel îndepărtat rămânea foarte rezervat [6].

\section{Vellan I., 1894 - „Despre amyotrofiile precoce consecutive pleuresiei acute şi pneumoniei““}

Contribuţie ştiinţifică: 1 . În cursul unei pleurezii acute și chiar al unei pneumonii, se putea observa atrofia mușchilor peretelui toracic. Această atrofie era precoce, așa că zece zile de la debutul maladiei erau suficiente în unele cazuri ca să fie manifestă.
2. În general, debutul era brusc, rapid, fără fenomene subiective și putea interesa toți mușchii toracici de partea bolnavă, fără a cruța câteodată nici deltoidul corespunzător. În privința acestei distribuții, nu există nicio regulă și puteau fi întâlnite asocieri. 3. $\mathrm{Nu}$ se putea stabili nicio relație între intensitatea procesului morbid și apariţia lor pentru că pleureziile cu reacții inflamatorii minime puteau fi însoțite de amiotrofii destul de evidente. De asemenea, nu era imposibil să se stabilească exact condițiile care determinau diferențe contradictorii, asta cu toată minuțiozitatea cu care au fost examinați bolnavii. Nu s-a putut să reiasă măcar acele predispoziții nervoase, ereditare sau dobândite, care erau mult evocate în aceste împrejurări. 4. Leziunile anatomopatologice care au fost găsite constau în: atrofii simple ale ramurilor mici nervoase însoțite de dispariția mielinei și de o fragmentare și umilare neregulată a segmentelor interanulare; o dezintegrare parte granuloasă, parte grăsoasă a mielinei și o proliferare a nucleilor diferitelor teci, atât interne, cât și externe. Din punct de vedere muscular, s-a constatat: starea hialină a fibrelor, proliferarea nucleilor sarcolemului și a țesutului interfascicular, în inegalitate mare de volum a fibrelor, semnele unei iritații destul de evidente. Existau și regiuni destul de întinse unde fibrele erau normale și cele alterate erau găsite în vecinătatea unor părți în care vasele mici arătau semnele unei proliferări din jurul lor și chiar a endoteliului lor. În toate aceste regiuni, era găsită o atrofiere remarcabilă a țesutului grăsos care contri-

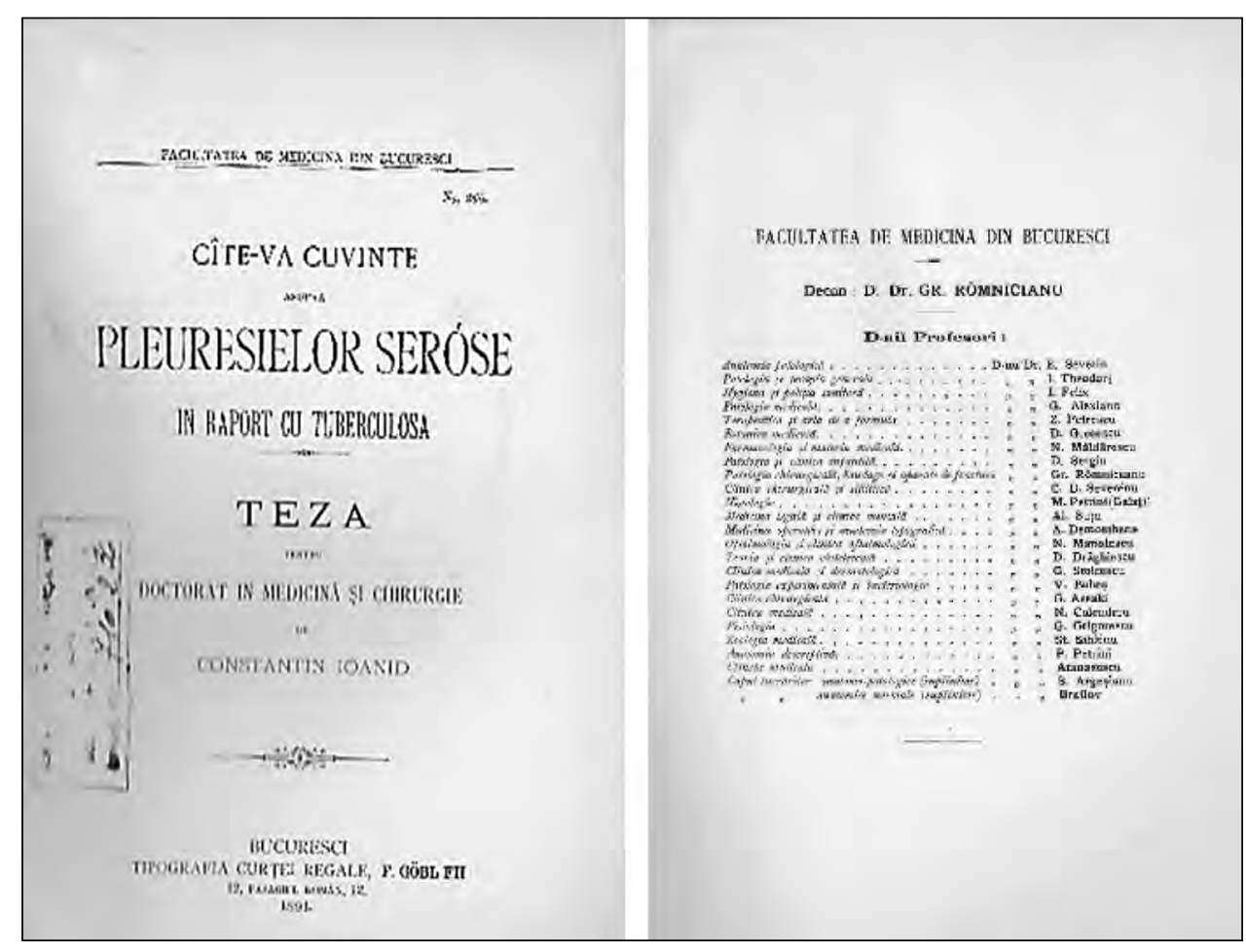

FIGURA 5. Lucrarea Dr. Ioanid Constantin, 1891 
buia mult la micşorarea de volum a masei musculare. 5. Teoria patogenică cea mai acreditată era cea refleză; nu putea fi negată nici influența propagării inflamației pe cale vasculară, teorie propusă de Prof. Dr. V. Babeș și bazată pe leziunile anatomopatologice găsite la 2 indivizi. 6 . Nu a putut fi constatată niciodată reacția de degenerescență propriuzisă. Într-un singur caz, a fost găsită modificarea parțială, iar în toate celelalte o modificare simplă cantitativă atât a excitabilității faradice, cât și a celei galvanice. 7. Prognosticul în general părea favorabil și, deși existau chiar vindecări spontane, totuși, tratamentul nu trebuia neglijat. Mijloacele cele mai recomandate erau disațiunea și stricnina sub orice formă la interior [7].

\section{Cimpeanu M., 1896 - „Studiul analitic asupra diferitelor tratamente în tuberculoza ganglionară cervicală"“}

Contribuţie ştiinţifică: 1. Tratamentul local extern, asupra ganglionilor nesupurați, își avea rațiunea sa, întrucât se dorea combaterea unei exacerbări inflamatorii acute sau a unei inflamații periganglionare, dar nu se putea pretinde mai mult. 2. Injecţiile intraganglionare cu oleiţi sau glicerină iodoformată și cu naftol camforat au dat câteodată rezultate bune, dar acțiunea lor era foarte des infidelă. 3. Extirparea ganglionilor cervicali trebuia condamnată, căci era mereu incompletă și ineficace și foarte des primejdioasă prin rezultatele ei depărtate. 4. Incizia abceselor ganglionare și răzuirea eventuală a unor fungosităţi, ce erau prezente în plagă, erau recomandate pentru că ajutau la eliminarea unor produse ce nu se puteau resorbi. 5. Pansamentul ulcerelor și fistulelor ganglionare trebuia făcut cu diferite antiseptice, alternativ întrebuințate. Cele mai preferabile erau: eterul iodoformat, balsamul peruvian, oleiul gaiacolat și clorura de zinc. $\mathrm{Cu}$ întrebuințarea lor alternativă, pentru că ajută mai bine cicatrizarea. 6 . Nu există niciun tratament specific contra adenopatiilor tuberculoase, precum nu există niciunul contra tuberculozei, în general. 7. Un tratament rațional, în care tratamentul general să predomine, părea a fi cel mai eficace. Deci, trebuia pus bolnavul în condiții igienice cât mai perfecte, să-i asigure un aer sănătos și chiar medicamentos, precum cel marin, o alimentație bună, hidroterapia și alte mijloace multiple care să îmbunătățească starea generală printr-o medicație rațională. Atunci, de multe ori, afecțiunea se vindeca de la sine, dar, dacă interveneau prin vreunul dintre mijloacele de mai sus, aveau garanția unui succes persistent [8].

\section{Ditzulescu Firu, 1897 - „Tratamentul pneumoniei acute la adulți prin baia rece“"}

Contribuţie ştiinţifică: 1. Pneumonia, boala infecțioasă și infectantă, nu avea tratament specific. $\mathrm{Nu}$ putea fi tratată boala, se mulțumeau a îngriji pe bolnav, punându-1 în condiții favorabile pentru a duce la bun sfârșit greutatea bolii. Era folosită medicație simptomatică, combătând sau prevenind simptomele bolii. 2. Indroterapia constituia singura indicație, prin proprietățile sale multiple, un trata-

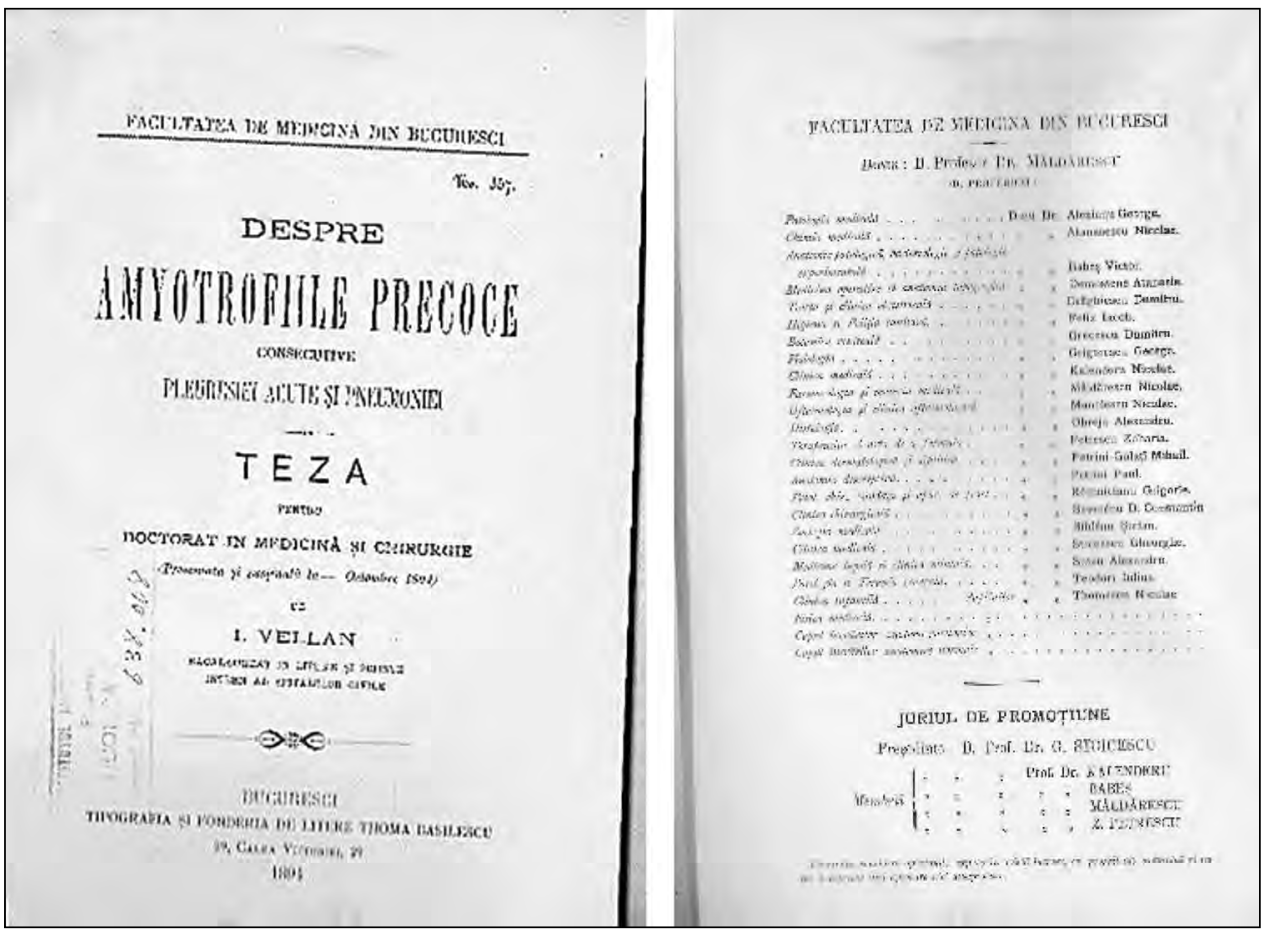

FIGURA 6. Lucrarea

Dr. Vellan I., 1894 


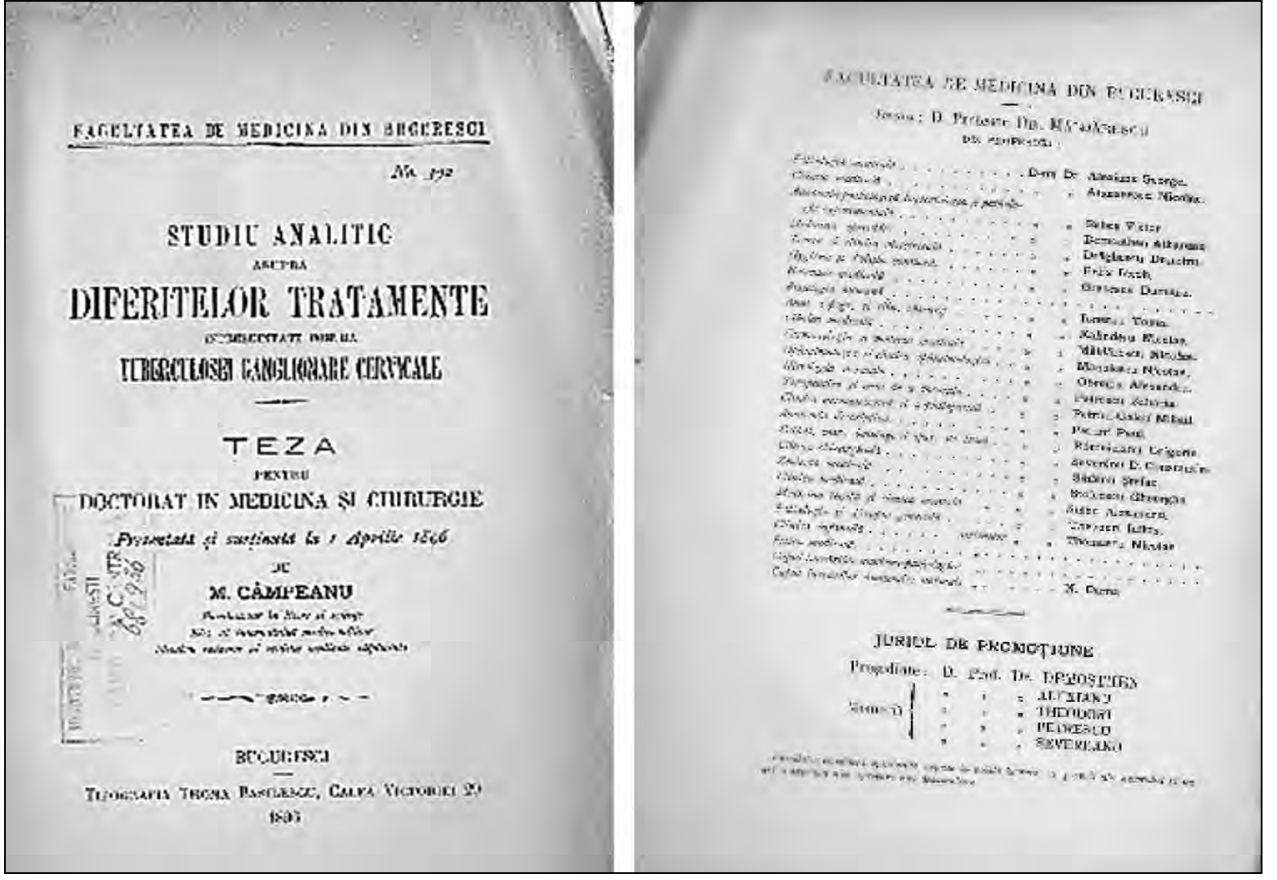

FIGURA 7. Lucrarea

Dr. Cimpeanu M., 1896 ment practic și rațional. 3. Toate cazurile de pneumonii acute erau susceptibile de tratament idric, cu excepția situației în care starea mușchiului cardiac și a vaselor sanguine, cu sau fără o etate prea înaintată a bolnavului, nu constituia o contraindicație a medicației refrigerante, cu toate că, prin întrebuințarea tonicelor și stimulantelor, puteau fi prevenite posibile accidente. 4. Instituită de la începutul bolii, baia rece lucra nu numai ca antitermic dar îndeplinea și profilaxia fenomenelor generale, precum și a insuficienței cardiace. 5. Ciclul pneumoniei nu era influențat. Baia rece nu oprea dezvoltarea bolii, defervescența se făcea de obicei între a 5-a și a 7-a zi, foarte rar peste această dată. Rezoluția epatasiunii pulmonare nu numai că nu era întârziată, dar părea a se efectua cu oarecare rapiditate și complet, într-un timp relativ scurt. 6. Băile reci aveau avantajul că, îndeplinind indicaţiile de mai sus, scurtau foarte mult perioada de convalescență, restabilirea bolnavului făcându-se destul de repede [9].

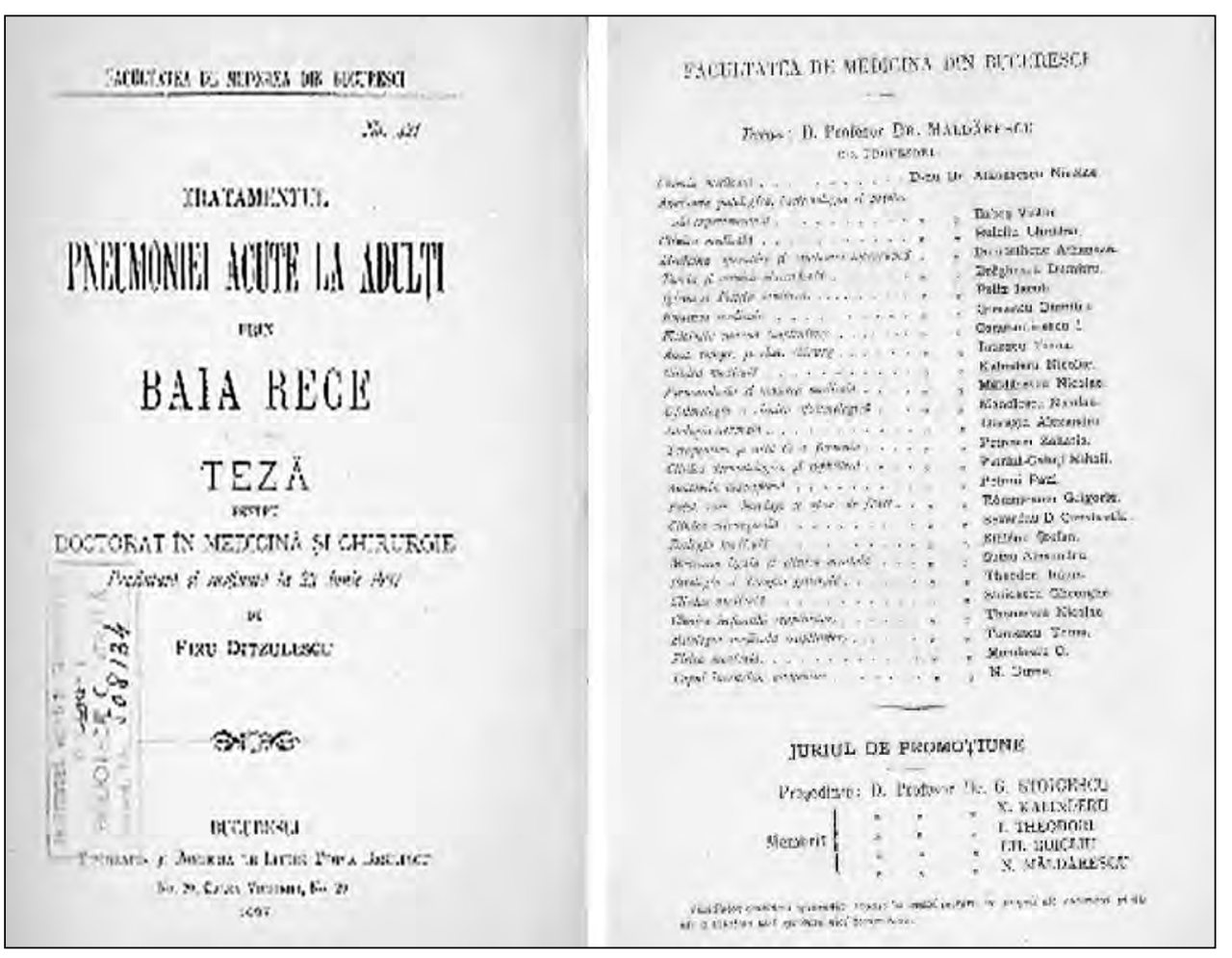


Berman M. losef, 1898 - „Contribuțiuni la studiul tratamentului peritonitei tuberculoase prin laparotomie“"

Contribuţie ştiinţifică: 1 . In peritonita tuberculoasă, indiferent de varietate, era justificabil un singur tratament: laparotomia. 2. Practicată după regulile antisepsiei și asepsiei, pericolele pentru laparotomie erau nule. 3. Deschiderea cavității ab- dominale constituia elementul esențial al terapiei chirurgicale. 4. Rezultatele obținute prin tratamentul chirurgical făceau să fie preferat mijloacelor medicale, care doar completau intervenția chirurgicală. 5. Modul de acțiune al laparotomiei în vindecarea peritonitei tuberculoase nu se cunoștea încă. 6. Experiențele pe animale au confirmat eficacitatea laparotomiei [10].

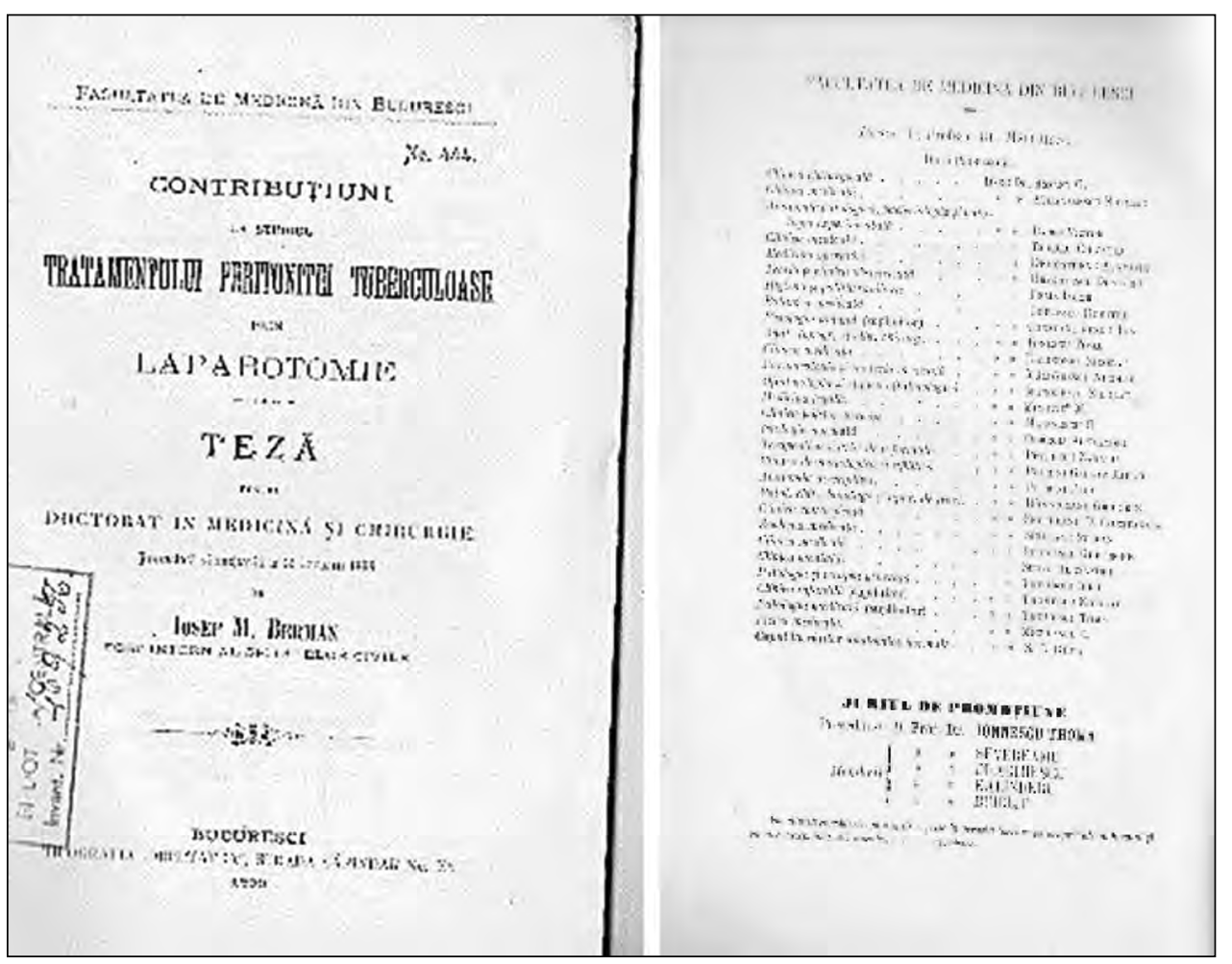

FIGURA 9. Lucrarea Dr. Berman M. losef, 1898

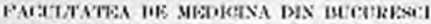

$$
\text { Na. } s \times
$$

CÁTE-VA CuVINTE neutre :.

DIAZO-REACTIUNBA LUI BHRLICH

III TUBERCULOZA

T E Z A

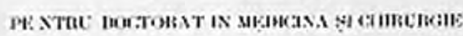

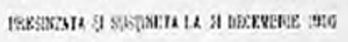

C. REDEZEANU

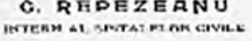

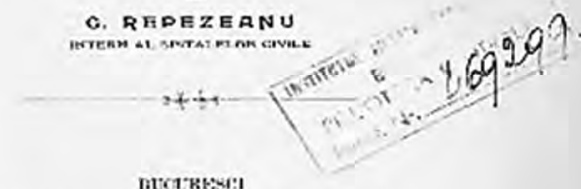

Bucchr:e:!

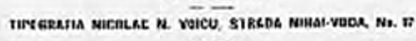

1900 


\section{Repezeanu C., 1900 - „Câte-va cuvinte relative la diazo-reacțiunea lui Ehrlich în tuberculoză“}

Contribuţie ştiinţifică: 1. Diazo-reacțiunea era negativă în urina celor sănătoși. 2. Cauza diazoreacțiunei lui Ehrlich nu era complet elucidată. Corpul, care o producea, era considerat ca un produs toxic eliminat prin urină, având proprietatea de a se combina cu corpii diazoici. 3. Diazo-reacțiunea era constatată în toate afecțiunile grave infecțioase. 4. Diazo-reacțiunea se constată și în tuberculoză, mai des în tuberculoza miliară, decât în tuberculoza localizată pulmonar, acută sau cronică. 5. Când fenomenele pulmonare erau puțin remarcabile, când sputa lipsea și bolnavul era apiretic, diazoreacțiunea găsindu-se în mod constant, era de un mare ajutor pentru stabilirea diagnosticului de tuberculoză. 6 . Prezența constantă și intensă a diazo- reacțiunei în tuberculoza pulmonară era de un prognostic iminent grav fatal, făcând abstracție chiar de aparențele benigne ale afecțiunii [11].

\section{CONCLUZII}

Am iniţiat un studiu care să pună în valoare meritele școlii românești de medicină și în special pe ale celei de pneumoftiziologie. Am folosit ca metodă cercetarea bibliografică prin studierea surselor, ordonarea cronologică, sintetizarea și interpretarea lor. Lucrările de doctorat studiate au fost realizate în cadru academic sub îndrumarea unor personalități medicale ale timpului, care s-au perfecționat și specializat în mari centre universitare europene, aducând medicina românească şi de specialitate la un nivel înalt, folosind toate realizările vremii.

Conflict of interest: none declared Financial support: none declared

\section{BIBLIOGRAFIE}

1. Pele $A$, Pele $S$. Scurtă introspecție în trecutul pneumologiei românești - O societate medicală în căutarea propriei identități, sub redacția Prof. Dr. Mihălțan F. Societatea Română de Pneumologie, București, 2009.

2. Corsin I. Câte-va cuvinte asupra tuberculosei ganglionilor limfatici la copii. Tipo.Litografia Dor. P. Cucu, Bulevardul Elisabeta, București, 1885.

3. Staiculescu G. Meningita tuberculoasă la copii. Tipografia Curții Regale București, 1886.

4. Andrescu V. Cercetări microbiologice asupra naturei absceselor peritoracice, dise tuberculose. Tipografia Curții Regale, București, 1887.

5. Basilescu E.I. Despre tuberculosa vesicală. Tipo.Litografia Dor. P. Cucu Bulevardul Elisabeta, București, 1887.

6. Ioanid C. Câte-va cuvinte asupra pleuresielor serose în raport cu tuberculosa. Tipografia Curții Regale, București, 1891.

7. Vellan I. Despre amyotrofille precoce consecutive pleuresiei acute şi pneumoniei. Tipografia și Fonderia de Litere Thoma Basilescu, Bucuresti, 1894.

8. Cimpeanu M. Studiul analitic asupra diferitelor tratamente în tuberculoza ganglionară cervicală. Tipografia și Fonderia de Litere Thoma Basilescu, București, 1896.

9. Ditzulescu F. Tratamentul pneumoniei acute la adulți prin baia rece, Tipografia și Fonderia de Litere Thoma Basilescu, București, 1897.

10. Berman M.I. Contribuţiuni la studiul tratamentului peritonitei tuberculoase prin laparotomie. Tipografia Dreptatea, București, 1898.

11. Repezeanu C. Câte-va cuvinte relative la diazo-reacţiunea lui Ehrlich în tuberculoză. Tipografia Nicolae N. Voicu, București, 1900. 